\title{
The main criteria for the formation of communicative universal educational actions in primary school children with learning disabilities
}

\author{
Marina Skuratovskaya ${ }^{1, *}$, Elena Romanova ${ }^{2}$ \\ ${ }^{1}$ Don State Technical University, 1, Gagarin sg, 344003, Rostov-on-Don, Russia
}

\begin{abstract}
The article deals with the characteristic features of speech development of primary school children with learning disabilities, due to the peculiarity of the development of their cognitive activity. The main types of communicative universal educational actions are analyzed. Criteria for assessing the level of development of communicative universal educational activities in younger students with learning disabilities are highlighted. The significance of these criteria for determining the directions of correctional and developmental work in educational and extracurricular activities for the development of communicative universal educational actions is substantiated.
\end{abstract}

\section{Introduction}

The rapid socio-economic and political changes taking place in the modern world are the main reason for changes in education, changing the perception of its goals and objectives [1]. If earlier the main results of education were the acquisition of knowledge, skills, and abilities, then in the post-industrial information society, the learning process is understood as preparing students for real life, mastering communications that will allow them to adapt to constantly changing conditions, and be ready to cooperate in various areas of life [2]. This approach is particularly relevant for students with learning disabilities. This is due to the peculiarities of their cognitive activity, speech and communication development [3].

In accordance with the Federal educational standard of primary education for children with disabilities, the formation of universal educational actions among students that ensure the child's ability to learn, independently solve the tasks that arise in their educational activities and in life, is currently one of the results of education [4].

\section{Purpose of the Present Study}

Universal learning activities that a student should master in the course of learning activities provide mastery of key competencies that form the basis of the ability to learn [5].

\footnotetext{
* Corresponding author: marinasku@yandex.ru
} 
An important group of universal learning activities consists of communicative universal learning activities that involve the ability to interact, actively participating in both dialogue and collective discussion of problems, as well as to carry out productive cooperation with adults and peers [6].

Communication problems of students with learning disabilities were studied by leading Russian defectologists K. S. Lebedinskaya [7], V. V. Lebedinsky [8], V. B. Nikishina [9] and others. There were such specific features of speech that make communication difficult for this group of schoolchildren, as difficulties in formulating their thoughts, in the correct selection of words, agrammatism, as a result of violations in the development of grammatical and syntactic patterns [10].

The problem of communication development of students with learning disabilities is particularly relevant at the present time due to the development of an inclusive form of education and the lack of readiness of primary school teachers to teach such students in inclusive classes. One of the reasons for this lack of readiness is that teachers are not aware of the features of the communicative development of students with learning disabilities and the corresponding special educational needs, and there is almost a complete absence of teachers in schools-defectologists. "The teacher-defectologist has special correctional, including electronic, technologies for teaching and educating children with disabilities and disabled people, has a basic education as a special school teacher and even a $\mathrm{PhD}$ degree. In addition, it is necessary to understand that without the use of specially developed individual educational programs, the child, in the learning process, has secondary disorders of mental development, emotional-volitional and personal spheres, which prevents successful integration into society and, consequently, socialization." [11].

In the process of formation of communicative universal educational actions, the younger the student learns to consider the opinion of the interlocutor that is different from their own; to justify one's own position; to make a common decision in the process of cooperation, resolve conflicts, given the positions of the interlocutors; to convey to the source information with the goal of creating guidelines for construction activities; formulate and ask questions; to solve communicative tasks using speech tools [12]. Communicative universal learning actions are the basis of successful learning, since it is impossible to talk about the effectiveness of learning without communication with the teacher and students [13].

\section{Theoretical and methodological approaches to the organization of psychological and pedagogical support}

According to the concept of development of universal educational actions in students, the authors of the concept (A. G. Asmolov, N. G. Salmina, G. V. Burmenskaya, O. A. Karabanova, I. A. Volodarskaya and S. V. Molchanova) distinguish three groups of communicative universal educational actions in accordance with the aspects of communicative activity [14].

The first group of communicative actions defines communication as interaction. Leading in this group is the ability to understand and accept the position of the interlocutor [6]. According to the Federal state educational standard of primary education, the results of mastering this aspect of communicative universal educational actions by students are the ability to ask questions, consistently build a monologue that is understandable to the interlocutor; formulate their own position in accordance with the norms of the Russian language.

The analysis of skills that determine the formation of the first group of communicative universal educational actions - communication as interaction, allows us to conditionally differentiate them into two types of skills. First, these are speech skills as the basis and, 
secondly, socio-psychological skills that make up the psychoemotional basis of communication as interaction. Speech skills are represented by the ability to correctly and clearly express their thoughts to others in oral and written form, ask questions and answer them. Socio-psychological skills are manifested in the ability to convey their own position and opinion to the interlocutor.

The second group of communicative actions consists of communicative actions that provide cooperation. Such actions include communicative actions that provide the ability to coordinate joint actions to achieve a goal based on an attentive attitude to the partner in the activity [14]. Communication as cooperation is manifested in such skills as the ability to offer help and ask for help yourself, clearly articulating your difficulties. This group also includes the ability to ask questions and initiate joint activities in solving various tasks.

As we can see, this group of communicative universal educational actions includes not only socio-psychological skills that determine the psycho-emotional side of interaction (mutual understanding, reflection of one's own actions, etc.), but also speech skills (speech communication in the process of distributing actions, exchanging methods of action, etc.).

Finally, the third group of communication skills includes skills that reveal communication as a condition for interiorization. This group includes communication actions that provide the necessary information and transfer information that sets guidelines for future joint activities. This group also includes communicative actions that allow you to assign roles and coordinate your actions with others [15]. The analysis of the communicative actions included in the third group also allows, as in the first and second groups, to differentiate all actions into speech and socio-psychological ones. Speech actions include communicative actions that provide the opportunity to get the necessary information through questions and convey important guidelines for upcoming activities in speech. Social and psychological communicative actions include the ability to ask for help and offer help, and formulate your own opinion.

From this classification, it becomes clear that the level of development of communicative universal educational actions directly depends on the level of general and speech development of the student. Among children with special educational needs, one of the most numerous in primary school is children with learning disabilities. They have marked and persistent violations not only of the cognitive, but also of the emotionalvolitional sphere [16]. For younger students with learning disabilities, a decrease in the stability of attention and performance, a decrease in short-term and long-term memory, as well as insufficient formation of educational motivation is characteristic [17].

Specific features are also characteristic of the speech development of primary school children with learning disabilities, including speech skills [18]. In special studies, there is a poor vocabulary [19], underdevelopment of the grammatical structure of speech, a low level of development of Dialogic and especially coherent monologue speech [20]. These features lead to difficulties in mastering reading and writing, which is manifested in various forms of dysgraphy and dyslexia in primary school students with learning disabilities.

The specifics of the communicative development of children with learning disabilities can also be traced in the features of the formation of socio-psychological skills, which is manifested in a decrease in activity in interaction with others, the inability to make contact and maintain it, to respond adequately to the emotional state of the interlocutor, and changes in the conditions of communication [21].

The results of the analysis of research on the problem of speech and socio-psychological development of younger schoolchildren with learning disabilities showed that this group of schoolchildren has significant features of the development of speech and sociopsychological basis of communicative universal educational actions caused by a violation of their cognitive activity [22]. At the same time, it was not possible to find special studies 
devoted to the study of the features of formation of communicative universal educational actions in younger schoolchildren with learning disabilities .

The analysis of the communicative skills that form the basis of universal communicative educational actions in primary school students with learning disabilities allowed us to differentiate them into two types, depending on the aspect of communication they implement: speech and socio-psychological.

Speech skills form the speech basis of communicative universal educational actions. This group includes such skills as the ability to ask questions, the ability to build statements that are understandable in accordance with the grammatical norms of Russian language; conduct an oral and written dialogue, and convey in speech the main guidelines for actions that will be understandable to the interlocutor [23].

The socio-psychological basis of communicative universal educational actions is formed by socio-psychological skills. These skills include the ability to formulate your own opinion and position, ask for help and offer cooperation, take the initiative in interaction, solving various tasks, and come to a mutual agreement on the distribution of roles in joint activities [24].

These speech and socio-psychological communication skills are crucial and can serve as criteria for the level of development of universal communicative learning activities. According to the above groups of communicative actions (communication as interaction, communication as cooperation, communication as a condition of interiorization), the criteria were divided into criteria for evaluating speech skills and criteria for evaluating socio-psychological skills for each of the groups of communicative actions. Groups of criteria for evaluating communicative universal learning activities are shown in the table 1 .

Table 1. The assessment criteria of communicative universal educational actions.

\begin{tabular}{|c|c|c|}
\hline \multirow{2}{*}{$\begin{array}{c}\text { Groups of } \\
\text { communicative actions }\end{array}$} & \multicolumn{2}{|c|}{$\begin{array}{c}\text { The assessment criteria of communicative universal learning } \\
\text { activities }\end{array}$} \\
\hline & $\begin{array}{c}\text { Criteria for evaluating } \\
\text { speech skills }\end{array}$ & $\begin{array}{c}\text { Criteria for evaluating socio- } \\
\text { psychological skills }\end{array}$ \\
\hline $\begin{array}{l}\text { Communication } \\
\text { interaction }\end{array}$ & $\begin{array}{l}\text { - ability to convey in speech } \\
\text { essential guidelines for actions } \\
\text { that are clear to the } \\
\text { interlocutor; } \\
\text { - ability to get the necessary } \\
\text { information by asking } \\
\text { questions; }\end{array}$ & $\begin{array}{l}\text { - ability to come to a common } \\
\text { decision in the distribution of } \\
\text { functions and roles in joint } \\
\text { activities; } \\
\text { - emotional attitude to joint } \\
\text { activities; }\end{array}$ \\
\hline $\begin{array}{l}\text { Communication } \\
\text { cooperation }\end{array}$ & $\begin{array}{l}\text { - ability to convey in speech } \\
\text { essential guidelines for actions } \\
\text { that are clear to the } \\
\text { interlocutor; } \\
\text { - ability to get the necessary } \\
\text { information using questions; } \\
\text { - the ability to articulate their } \\
\text { difficulties; }\end{array}$ & $\begin{array}{l}\text { - ability to come to a common } \\
\text { decision in the distribution of } \\
\text { functions and roles; } \\
\text { - ability to show initiative in } \\
\text { the process of cooperation, } \\
\text { solving various tasks; } \\
\text { - ability to ask for help, as well } \\
\text { as offer assistance and } \\
\text { cooperation; }\end{array}$ \\
\hline $\begin{array}{l}\text { Communication } \\
\text { condition } \\
\text { interiorization }\end{array}$ & $\begin{array}{l}\text { - ability to build statements } \\
\text { that are clear to the partner; } \\
\text { - ability to get the necessary } \\
\text { information using questions; } \\
\text { - ability to conduct oral and } \\
\text { written dialogue, conforming } \\
\text { to the grammatical and } \\
\text { syntactic norms of the Russian } \\
\text { language. }\end{array}$ & $\begin{array}{l}\text { - understanding different } \\
\text { positions and points of view, } \\
\text { focusing on the positions of } \\
\text { other people other than your } \\
\text { own; } \\
\text { - ability to formulate your own } \\
\text { opinion and position; }\end{array}$ \\
\hline
\end{tabular}




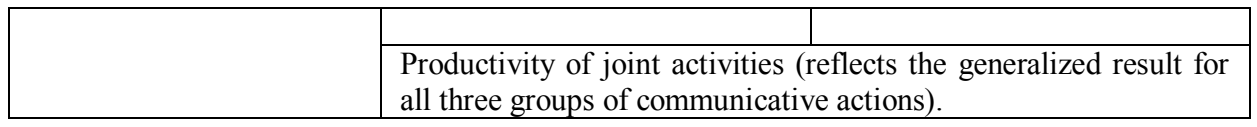

The results of the study of communicative universal educational actions, speech skills that form their basis, allowed us to clarify the concept of "communicative universal educational actions" from the position of our approach. We define communicative universal educational actions as the most important personal neoplasm formed in the process of education, which provides the ability to interact with others in the process of joint activity, has a complex structure and includes speech and socio-psychological components represented by the corresponding communicative actions.

\section{Conclusion and recommendation}

The analysis of modern ideas about communicative universal educational actions as a component of universal educational actions allowed us to come to the following conclusions.

Communicative universal learning activities are the most important personal neoplasm formed in the process of education. They have a complex structure and include speech and socio-psychological components.

The formation of universal learning activities is one of the important results of learning the educational program. Communicative universal learning activities constitute an important group of universal learning activities that provide the ability to interact with others in the process of joint activities using various means of communication.

Formation of communicative universal educational actions in students with learning disabilities is difficult, which is explained by the peculiarities of their speech development, cognitive and emotional-volitional sphere. Evaluation of universal communicative learning activities should be based on clear criteria that determine the development of communicative actions.

Communicative universal educational actions are represented by a number of communicative actions, which, depending on the implemented aspect of communication, can be differentiated into speech and socio-psychological ones. Each of the groups of communicative actions (communication as interaction, communication as cooperation, communication as a condition of interiorization) corresponds to certain speech and sociopsychological communicative actions that can serve as criteria for assessing the level of development of communicative universal educational actions.

In the works devoted to the study of communicative universal educational actions, groups of communicative actions were identified: communication as a prerequisite for interiorization, communication as cooperation and communication as interaction.

The analysis of works in the field of studying communicative universal educational actions of younger schoolchildren allowed us to systematize the results of the study and distinguish two groups of skills: speech and socio-psychological. These two groups of skills form the basis of each of the three components of communicative universal learning activities, which can serve as criteria for their formation in the process of diagnostic and correctional work.

Using the selected criteria, it is also possible to develop a comprehensive methodology for the formation of speech and socio-psychological skills of communicative universal educational actions for each of the three structural components. The solution to these problems will be presented in future publications. 


\section{References}

1. L.M. Troesch, K. Keller, A. Grob, European Psychologist 21(3), 167-179 (2016)

2. D.F. Hay, A. Payne, A. Chadwick, Journal of Child Psychology and Psychiatry 45(1), 84-108 (2004)

3. G. Laws, G. Bates, M. Feuerstein, E. Mason-Apps, C. White, Child Language: Teaching and Therapy 28(1), 73-86 (2012)

4. A.V. Barannikov, Content of General education. Competence approach (Higher school of Economics, Moscow, 2002)

5. R.A. Dunilova, Management of the elementary school 5, 15-22 (2013)

6. How to design universal educational actions in primary school: from action to thought: a guide for teachers (Enlightenment, M., 2008)

7. K.S. Lebedinskaya, Defectology 3, 15-27 (2006)

8. V.V. Lebedinsky, Violations of mental development of children (Academy, Moscow, 2003)

9. V.B. Nikishina, Practical psychology in working with children with ZPR: a guide for psychologists and teachers (Humanitar. Izd. center VLADOS, Moscow, 2003)

10. S. Graham, K.R. Harris, Research \& Practice, 28-37 (2013)

11. L.M. Kobrina, Innovation and tradition, science and education all-Russian scientificpractical conference (Syktyvkar, 2010)

12. M.E. Gifford-Smith, C.A. Brownell, Journal of School Psychology 41(4), 235-284 (2003)

13. L.I. Lazareva, Elementary school 6, 76-78 (2014)

14. N.V. Osipova et al, Primary school management 10, 44-47 (2010)

15. L.Y. Chadaeva, Management of elementary school 6, 32-36 (2013)

16. S.M. Murphy, D. Faulkner, European Journal of Psychology of Education 15(4), 389404 (2000)

17. E.V. Sokolova, Psychology of children with delayed psychological development: textbook (Moscow, 2009)

18. W.V. Olenkova, Children with mental retardation (N. Novgorod, 1994)

19. Special psychology: textbook. the allowance (Vysh. SHK, Minsk, 2012)

20. S.M. Redmond, Language, Speech, and Hearing Services in Schools 42(4), 520-535 (2011)

21. R.D. Triger, Psychological features of socialization of children with mental retardation (Piter, Saint Petersburg, 2008)

22. B. Menting, P.A.C. Van Lier, H.M. Koot, Journal of Child Psychology and Psychiatry 52(1), 72-79 (2011)

23. F. Van der Wilt, C. Van der Veen, C. Van Kruistum, B. Van Oers, Educational Psychology 31(3), 699-724 (2019)

24. F. Van der Wilt, C. Van Kruistum, C. Van der Veen, B. Van Oers, European Early Childhood Education Research Journal 24(6), 807-817 (2016) 